\title{
Gunshot Fractures to the Limbs: A Review of Fixation Methods
}

\author{
Captain Daniel Ribeiro Mesquita ${ }^{1 *}$, Lieutenant Maurício Gomes Arcoverde ${ }^{2}$ and Major Joel Paulo \\ Akerman ${ }^{3}$
}

${ }^{1}$ Military Orthopedic Surgeon of the Brazilian Army; Orthopedic Surgeon, Army Central Hospital; Orthopedic Surgeon, Salgado Filho Emergency Hospital; Board of the Brazilian Society of Orthopedics and Traumatology and the Brazilian Society of Knee Surgery, Rio de Janeiro, Brazil

${ }^{2}$ Military Doctor of the Brazilian Army; Military Doctor, Army Central Hospital; Resident, Department of Orthopedics and Traumatology, Salgado Filho Emergency Hospital, Rio de Janeiro, Brazil

${ }^{3}$ Military Orthopedic Surgeon of the Brazilian Army; Chief, Department of Orthopedics and Traumatology, Army Central Hospital; Orthopedic Surgeon, Salgado Filho Emergency Hospital; Board of the Brazilian Society of Orthopedics and Traumatology, Rio de Janeiro, Brazil

\begin{abstract}
Background: The authors had intensive experience with gunshot fractures in wounded civilian and military in the war against organized crime in Rio de Janeiro. From the many difficulties and controversies, came the necessity to search for scientific evidence to establish management and treatment to these challenging injuries.

Purpose: Make a revision about fixation methods in the management and treatment of gunshot fractures to the limbs.

Material and methods/results: The author researched the combination of the terms "Fractures", "Gunshot", "Treatment", "Fixation" and "Orthopedic Surgery" in MEDLINE, PUBMED, SCIELO and LILACS.

Conclusion: Gunshot fractures Grade Gustillo I and II can be treated with debridement plus immediately/early internal fixation; Fixation methods remain controversial in Gustillo III fractures. More high level studies are necessary to establish protocols in Gustillo III gunshot fractures.
\end{abstract}

\section{Introduction}

Until the 1990s, the United States had virtually all of the published work on firearms injuries and in war situations. This may be due, in large part, to the fact that this country has participated intensively in the last armed conflicts of Humanity since the Second World War. More recently, with the increase in crime, the war against terrorism and the ease of access to military weapons, the treatment of these fractures has become no more exclusivity in situations of war. Studies in Africa, Asia and Latin America [1] presented relevant experiences in the approach to these lesions. The increase in violence in large urban centers around the world has resulted in injuries from firearms being treated in civilian hospitals, particularly in developing countries. In Brazil over the last 30 years, violence, drug trafficking and arms trafficking have grown on a large scale. Fractures from military weapons have been increasingly common in emergency hospitals in large Brazilian urban centers, such as the metropolitan areas of Rio de Janeiro and São Paulo. Epidemiological studies show that more than 40,000 people die each year from firearm injuries [2], most of them young adult men. In developed countries, especially in the United States, which continue to engage in constant military and combat military activity, treatment protocols are being improved for the most severely injured soldiers, especially in post-amputation rehabilitation and protection. The rehabilitation and rapid return of military combatants to their operational activities has been a reality in the recent Operations in Afghanistan and Iraq $[3,4]$. The present review article seeks data in the literature for fixation methods

*Corresponding author: Captain Daniel Ribeiro Mesquita, Military Orthopedic Surgeon of the Brazilian Army; Orthopedic Surgeon, Army Central Hospital; Orthopedic Surgeon, Salgado Filho Emergency Hospital; Board of the Brazilian Society of Orthopedics and Traumatology and the Brazilian Society of Knee Surgery, Rio de Janeiro, Brazil

Accepted: June 12, 2019

Published online: June 14, 2019

Citation: Mesquita CDR, Arcoverde LMG, Akerman MJP (2019) Gunshot Fractures to the Limbs: A Review of Fixation Methods. J Orthop Rheumatism 3(1):51-58 
in the surgical treatment of fractures by firearms.

After the ABCDE Primary Evaluation and Trauma Management, one of the first steps in orthopedic assessment is to investigate the mechanism of trauma and observe the characteristics of the wounds. Historically, gunshot wounds are divided into high and low speed. Results of ballistic studies obtained in the literature have shown that the impact of the lesion on the tissue at the moment of impact, the anatomical site affected, the distance of the shot and the degree of bone comminution $[5,6]$ are more important than the velocity to characterize the injuries. Fackler [5] observed that speed is only one of the severity factors of the lesion and is not considered a single criterion. Long [7] correlated the low speed lesions like Type Gustillo I Lesions and high speed lesions like Type Gustillo III. Classifying these lesions by high or low energy may not give the true dimension of severity and prognosis, with negative consequences for evaluation and treatment. Gustillo's classification for exposed fractures remains the ideal parameter for assessment of severity and prognosis of firearm fractures and should be used to the detriment of others in order to establish conducts in order to avoid serious complications such as infection $[8,9]$. In a multivariate study of predisposing factors for deep infection in open fractures Noumi [10] performed in Japan, covering 89 exposed femoral fractures in 88 patients. The study took into account gender, age, Gustillo's classification, AO classification, fracture segment, time and method of intramedullary fixation (milled or unmurtened), debridement time ( $>$ or $<6 \mathrm{~h}$ ), polytrauma and floating knee. After evaluating these variables, the authors concluded that the only parameter that acts as predisposing factor of infection is the Gustillo classification (Table 1).

\section{Material and Methods}

The authors researched the combination of the terms "Fractures", "Gunshot", "Treatment" and "Orthopedic Surgery" in MEDLINE, PUBMED, SCIELO and LILACS. After this primary research, criteria for inclusion and exclusion were stablished:

\section{Inclusion criteria}

1. Patients that were treated with gunshot injuries to the extremities and limbs

2. Clear description of the treatment

Table 1: Gustillo classification for open fractures.

\begin{tabular}{|l|l|}
\hline Gustillo and Anderson classification \\
\hline Grade I & $\begin{array}{l}\text { Clean skin opening of }<1 \mathrm{~cm} \text {, usually from inside to outside; minimal muscle contusion; simple transverse or short oblique } \\
\text { fractures }\end{array}$ \\
\hline Grade II & $\begin{array}{l}\text { Laceration }>1 \mathrm{~cm} \text { long, with extensive soft tissue damage; minimal to moderate crushing component; simple transverse or } \\
\text { short oblique fractures with minimal comminution. }\end{array}$ \\
\hline Grade III & $\begin{array}{l}\text { Extensive soft tissue damage, including muscles, skin and neurovascular structures: Often a high energy injury with severe } \\
\text { crushing component. }\end{array}$ \\
\hline Grade IIIA & $\begin{array}{l}\text { Extensive soft tissue laceration, adequate bone coverage; segmental fractures, gunshot injuries, minimal periosteal } \\
\text { stripping. }\end{array}$ \\
\hline Grade IIIB & $\begin{array}{l}\text { Extensive soft tissue injury with periosteal stripping and bone exposure requiring soft tissue flap closure; usually associated } \\
\text { with massive contamination }\end{array}$ \\
\hline Grade IIIC & Vascular injury requiring repair. \\
\hline
\end{tabular}

Table 2: Gustillo I gunshot fractures.

\begin{tabular}{|c|c|c|c|}
\hline Author/Journal & $\begin{array}{l}\text { Population/anatomical } \\
\text { Segment }\end{array}$ & $\begin{array}{l}\text { Methods } \\
\text { of fixation }\end{array}$ & Results \\
\hline $\begin{array}{l}\text { Wiss [12]/J Bone Joint Surg Am } \\
1991\end{array}$ & Civilian/Femur fractures & Delayed Interlocking Nailing & $\begin{array}{l}0 \% \text { infection; } 3.5 \% \text { delayed } \\
\text { union; } 12.5 \% \text { malunion }\end{array}$ \\
\hline $\begin{array}{l}\text { Bergmann [13]/J } \\
\text { Trauma } 1993\end{array}$ & Civilian/Femur fractures & $\begin{array}{l}\text { Immediate Intramedullary } \\
\text { Nailing }\end{array}$ & $0 \%$ infection \\
\hline $\begin{array}{l}\text { Nowotarski [14]/J } \\
\text { Orthop Trauma } 1994\end{array}$ & Civilian/Femur fractures & $\begin{array}{l}\text { Immediate Intramedullary } \\
\text { Nailing }\end{array}$ & $\begin{array}{l}0 \% \text { infection; } 2.5 \% \text { delayed } \\
\text { union; } 2.5 \% \text { malunion; } 0 \% \\
\text { nonunion. }\end{array}$ \\
\hline $\begin{array}{l}\text { Molinari [17]/Cont } \\
\text { Orthop } 1994\end{array}$ & $\begin{array}{l}\text { Civilian/Extremity long bone } \\
\text { fractures }\end{array}$ & $\begin{array}{l}\text { Immediate }(A) \text {, early } \\
\text { (B) and late }(C) \text { internal fixation } \\
\text { groups }\end{array}$ & $\begin{array}{l}\text { Infection } \\
2.6 \% \text { Nonunion } \\
3.3 \% \text { in each group }\end{array}$ \\
\hline $\begin{array}{l}\text { Tornetta [16]/J Orthop Trauma } \\
1994\end{array}$ & Civilian/Distal femur & $\begin{array}{l}\text { Anterograde Intramedullary } \\
\text { Nailing }\end{array}$ & $\begin{array}{l}\text { 7.8\% low valgus deformity; } \\
15.8 \% \text { low posterior angulation }\end{array}$ \\
\hline
\end{tabular}


Citation: Mesquita CDR, Arcoverde LMG, Akerman MJP (2019) Gunshot Fractures to the Limbs: A Review of Fixation Methods. J Orthop Rheumatism 3(1):51-58

\begin{tabular}{|c|c|c|c|}
\hline $\begin{array}{l}\text { Long [7]/Clin Orthop Rel Res } \\
2003\end{array}$ & Civilian/Injuries to the femur & Immediate or early nailing & No infection \\
\hline $\begin{array}{l}\text { Polat [15]/ } \\
\text { Eur J Trauma } \\
\text { Emerg Surg } 2018\end{array}$ & $\begin{array}{l}\text { Civilian/Femur } \\
\text { Diaphyseal fractures }\end{array}$ & $\begin{array}{l}\text { Immediate } \\
\text { debridement and } \\
\text { delayed treatment: } \\
\text { External fixation (group A) versus } \\
\text { Intramedullary Nailing (group B) }\end{array}$ & $\begin{array}{l}\text { Deep infection } \\
5.2 \%(\mathrm{~A}) ; 3.5 \%(\mathrm{~B}) \\
\text { Delayed union } \\
\text { 10.5\%(A); } 7.1 \%(\mathrm{~B}) \\
\text { Nonunion } 2.6 \%(\mathrm{~A}) 3.5 \%(\mathrm{~B})\end{array}$ \\
\hline $\begin{array}{l}\text { Gonzalez [18]/The } \\
\text { Journal of Hand Surgery } 1993\end{array}$ & $\begin{array}{l}\text { Civilian/Hand metacarpal } \\
\text { fractures }\end{array}$ & $\begin{array}{l}\text { Early rigid fixation combined } \\
\text { fixation with flexible } \\
\text { intramedullary nails, } \mathrm{k} \text { wires and } \\
\text { plates. }\end{array}$ & $\begin{array}{l}0 \% \text { deep infection; } 4 \% \text { superficial } \\
\text { infection; } 0 \% \text { malrotation; mild } \\
\text { decrease in range of motion. }\end{array}$ \\
\hline $\begin{array}{l}\text { Kiehn [19]/Plast } \\
\text { Reconstr Surg. } 2005\end{array}$ & Civilian/hand fractures & $\begin{array}{l}\text { Reduction and immobilization; } \\
\text { Early definitive fixation }\end{array}$ & $\begin{array}{l}8 \% \text { infection with no difference } \\
\text { between the methods. }\end{array}$ \\
\hline $\begin{array}{l}\text { Komurcu [20] Int Orthop } \\
2008\end{array}$ & $\begin{array}{l}\text { Civilian/Hand } \\
\text { fractures }\end{array}$ & $\begin{array}{l}\text { Immediate fixation for all plate } \\
\text { fixation (A), K wire (B) and Ext } \\
\text { Fixation (C), } \\
\text { Plate + graft (D) }\end{array}$ & $\begin{array}{l}\text { Infection } 14.2 \%(A) ; \\
30 \%(B) ; \\
28.5 \%(C) ; \\
10 \%(D) \\
\text { Nonunion } \\
0 \%(A, B) \\
7 \%(C) ; 10 \%(D) .\end{array}$ \\
\hline
\end{tabular}

Table 3: Gustillo II gunshot fractures.

\begin{tabular}{|l|l|l|l|}
\hline Author/Journal & Population/anatomical Segment & Methods of fixation & Results \\
\hline Long [7]/Clin Orthop Rel Res 2003 & Civilian/Injuries to the femur & Delayed Nailing (more than 48h) & 43\% infection \\
\hline
\end{tabular}

3. Clear description of the injuries

4. Clear description of the outcomes

5. Articles published after 1980

\section{Exclusion criteria}

1. Epidemiologic studies

2. Basic science studies

3. Articles involving patients with skeletal immaturity

4. Spinal injuries

\section{Results}

The articles selected for this review were organized in Table 2, Table 3 and Table 4 and they were divided according to the Gustillo Classification. If an article presents clear and relevant data about different types of fractures it can appear in more than one table.

\section{Discussion-Treatment}

\section{Gustillo I gunshot fractures}

Gunshot Fractures Gustillo I with good alignment and stability tend to be treated conservatively. These fractures are correlated to fractures by low energy firearms. It seems to be a consensus that conservative management is well indicated in less severe lesions. This is very important because of the antibiotic bacterial resistance and high costs of health administration. Papasoulis [11], in a systematic review, concluded that the use of antibiotics in uncomplicated lesions and with conservatively treated fractures can be ruled out. The antibiotics of choice are cephalosporins, cefazolin, with similar efficacy through intravenous or intravenous administration.

When surgical methods are needed, the treatment of choice is the immediate primary immediate fixation. However, it was observed that until the late 1970's and early 1980's, the conservative treatment of Gustillo I gunshot femoral fractures was still used. In the mid-1980s, comminuted and unstable femoral shaft fractures, including firearms, were being treated by intramedullary nail. Plates and screws had a higher incidence of deep infection due to larger incisions and exposure of soft tissues and external fixators had infection with pin traction and problems with knee rehabilitation and bone healing. In the 1990's, Wiss [12], Bergman [13] and Nowotarski [14] published non-comparative retrospective studies assessing the treatment of gunshot-induced femur fractures by early intramedullary nailing, all with good results and low rates of complications. The main limitation of these studies was the low level of evidence.

Gunshot femur fractures Gustillo type I are quite prevalent and their treatment has some controversy. Polat [15] analyzed 107 low energy gunshot-induced diaphyseal femur 
Citation: Mesquita CDR, Arcoverde LMG, Akerman MJP (2019) Gunshot Fractures to the Limbs: A Review of Fixation Methods. J Orthop Rheumatism 3(1):51-58

Table 4: Gustillo III gunshot fractures.

\begin{tabular}{|c|c|c|c|}
\hline Author/Journal & Population/anatomical Segment & Methods of fixation & Results \\
\hline $\begin{array}{l}\text { Dar [23]/Ulus Trauma acil } \\
\text { Cerrahi Derg } 2009\end{array}$ & War fractures by firearms & External Fixation & $0 \%$ malunion \\
\hline $\begin{array}{l}\text { Olasinde [24]/South African } \\
\text { Orthop Journal } 2012\end{array}$ & $\begin{array}{l}\text { Civilian/Inferior extremities } \\
\text { fractures }\end{array}$ & $\begin{array}{l}\text { Delayed Intramedullary Fixation } \\
\text { and bone grafting }\end{array}$ & $15.2 \%$ infection \\
\hline Dubravko [25]/J Trauma 1994 & Military/Extremities Fractures & External Fixation & $\begin{array}{l}7.7 \% \text { osteomyelitis } 35 \% \text { tract } \\
\text { pins infection }\end{array}$ \\
\hline $\begin{array}{l}\text { Kaguru [26]/East and Central } \\
\text { African Journal of Surgery } 2004\end{array}$ & $\begin{array}{l}\text { Military/War extremities } \\
\text { fractures }\end{array}$ & External Fixation & $\begin{array}{l}\text { 3.2\% psudoarthrosis; } 16.1 \% \\
\text { osteitis; } 1 \% \text { tetanus. }\end{array}$ \\
\hline Dahabra [27]/J Trauma 1994 & Military/Extremities fractures & External Fixation & $\begin{array}{l}23 \% \text { wound infection; } 10 \% \text { pin } \\
\text { tract infection }\end{array}$ \\
\hline $\begin{array}{l}\text { Lerner [28]/Clin Orthop Relat } \\
\text { Res } 2006\end{array}$ & $\begin{array}{l}\text { Military/war lower limbs } \\
\text { fractures }\end{array}$ & Ilizarov External Fixation & $90 \%$ good results \\
\hline Possley [29]/J Trauma 2010 & Military/Tibial fractures & External Fixation & $77 \%$ successful \\
\hline Amaral [30] Orthop Rel Res 2003 & Civilian/Forearm fractures & External fixation (A) vs. cast (B) & $\begin{array}{l}\text { A-57.1\% Satisfactory; } \\
\text { B-58.3\% satisfactory. }\end{array}$ \\
\hline Nikolic [31] Injury 1999 & $\begin{array}{l}\text { Military/Subtrochanteric } \\
\text { fractures }\end{array}$ & $\begin{array}{l}\text { External fixation }(A) \text { versus } \\
\text { plaster of Paris }(B)\end{array}$ & $\begin{array}{l}\text { Complications } \\
\text { overall: 65\%; infection: 15\%; } \\
\text { malunion: 10\%. } \\
\text { A-65\% (delayed healing } \\
\text { and nonunion; B-86.7\% } \\
\text { (contractures) }\end{array}$ \\
\hline
\end{tabular}

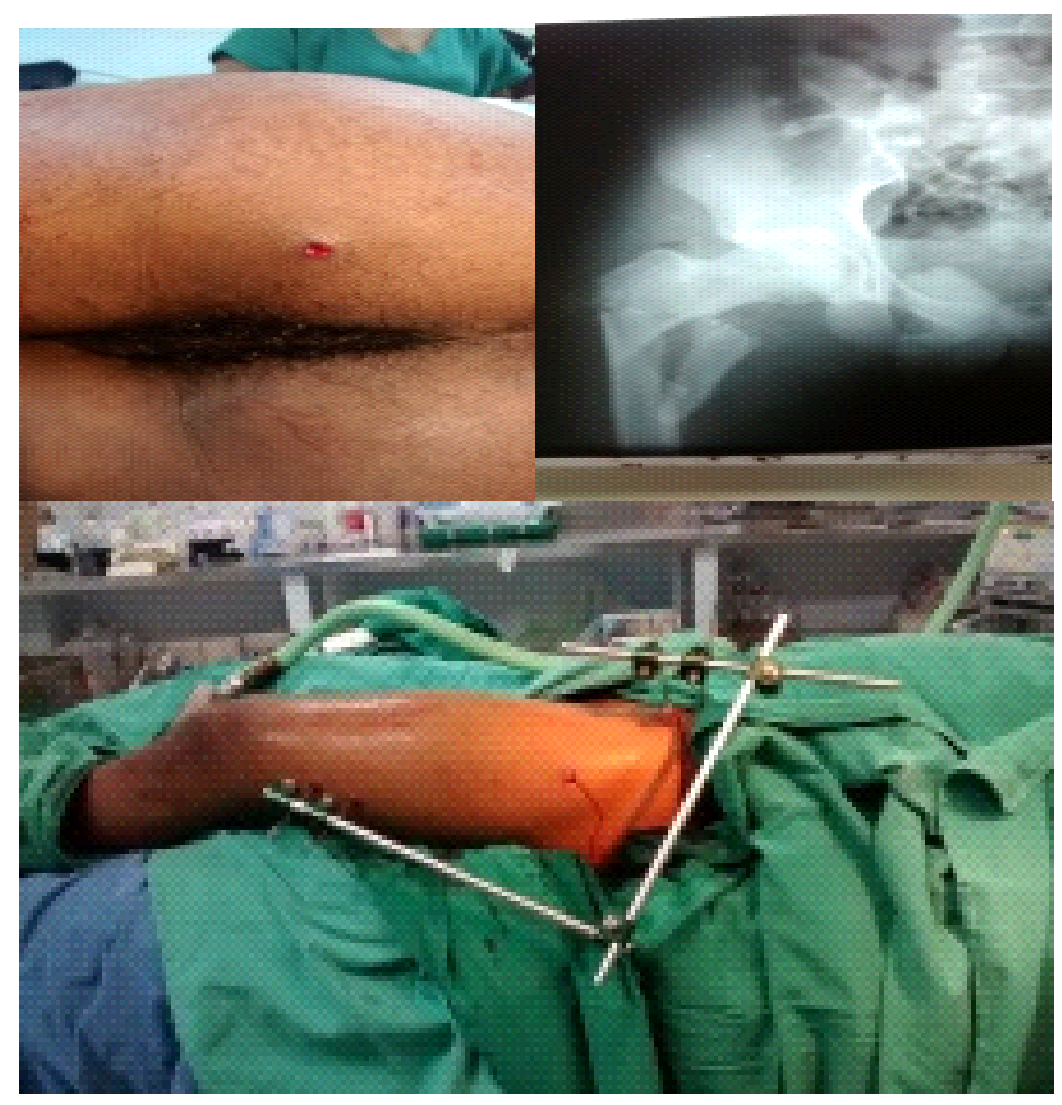

Figure 1: Transfixing Gustillo I gunshot fracture of the proximal femur a sciatic nerve neuropraxis treated with pelvifemoral external fixation at a trauma hospital in Rio de Janeiro. (Author's archive). 
fractures, comparing delayed external fixation and delayed nailing and no differences were found between these methods. Tornetta [16] retrospectively assessed 38 patients with distal femoral fractures by firearms in an average period of 24 months operated with anterograde intramedullary nail and obtained consolidation and early mobilization in all cases with rates of $22 \%$ of deviations greater than $5^{\circ}$ of angulation. Molinari [17] and Long [7], in comparative studies with femoral firearm fractures in civilians, had good results treating them with immediate intramedullary nail and low infection rates in cases with lower exposure bone ( $0 \%$ to $2 \%$ ). Molinari performed a comparative analysis of 121 Gustillo I long-bone firearm fractures in a New York City hospital, placing them in three groups according to the internal fixation time (immediate, precocious and late). No difference was found and the study concluded that early internal fixation is related to the reduction of hospital stay. Long studied 100 fractures of the femoral dyaphisis and classified according to the level of contamination in 1, 2 and 3. Immediate fixation was performed in fractures of Grade 1 with infection rate equal to $0 \%$. Polat [15] analyzed 107 grade I diaphysial femur fractures, comparing late external fixation and late fold, and no differences were found between these methods.

In some Gustillo I gunshot fractures, depending on the circumstances and other injuries associated, the treatment with external fixation can be done, especially when there are other injuries associated (Figure 1). In the war against crime in Rio de Janeiro, many conflicts are fought in places of high contamination and difficult access, near hills, forests and open air sewers. In addition, there are reports of drug traffickers who put feces in their armaments and projectiles to increase the contamination of wounds. Primary internal osteosynthesis may be at high risk of complicating infection, even in Gustillo I fractures.

On many occasions, it is not the degree of contamination of the fracture by firearm that determines the surgical technique, but the anatomical site. Fractures of the upper limbs by firearms present a very small amount of studies when compared to the inferior limbs. Nevertheless, some articles can be pointed out to be relevant to stablish management in Gustillo I upper limb gunshot fractures. Gonzalez [18] performed definitive stabilization in 64 cases of Gustillo I firearm hand fractures in 49 patients. The patients were initially approached with debridement, antibiotic therapy and immobilization. After an average of 3 days, definitive reconstruction with rigid fixation was performed. There were no cases of deep infection and $1.38 \%$ of surface infection. The shortening occurred on an average of $1.4 \mathrm{~mm}$. The mean final angle was $1^{\circ}$. The mean metacarpophalangeal foramen amplitude was $65^{\circ}$; the interphalangeal was $72^{\circ}$ and the distal $60^{\circ}$. Kiehn [19], in a restrospective descriptive study, pointed immediate definitive fixation methods and the best choice for definitive fixation in hand fractures by low energy firearms. Komurcu [20] compared osteosynthesis with plate and fixation with kirschner wires in hand fractures by low velocity firearms, in a total of 76 patients, 51 metacarpal fractures and 41 proximal phalangeal fractures. There were no significant differences between the methods used. The infection rate was $10.5 \%$, being $1.3 \%$ of deep infection and $9.2 \%$ of deep infection.

\section{Gustillo II gunshot fractures}

Gustillo grade II firearms fractures can be considered as of intermediate severity. Long [7], when discussing the treatment of firearm fractures with wounds greater than 2 $\mathrm{cm}$, emphasizes the importance of meticulous debridement and finds a $43 \%$ infection rate in these fractures. Comparing fracture complications with wounds less than $2 \mathrm{~cm}(0 \%$ of infection) with greater than $5 \mathrm{~cm}(50 \%)$, Gustillo II fractures would have more similarity to Gustillo grade III fractures than Gustillo grade I fractures. Regarding the technique of surgical fixation, Long recommends an early definitive fixation (less than 48 h) in grade 2 and late fixation in fractures grade 3. If the results of this study are correlated with the classic works of Gustillo and Anderson, it can be said that Gustillo II grade fractures with wounds bigger than $1 \mathrm{~cm}$ and smaller than $2 \mathrm{~cm}$, without bone devitalization may have a more conservative treatment, like Gustillo I. Those Gustillo II grade fractures with wounds bigger than $2 \mathrm{~cm}$ and tissue devitalization should have a more aggressive treatment, like Gustillo III. It is recommended in cases of doubt, look at other criteria to define the best approach, such as the time taken to hospital care, the circumstances and the anatomical site where the victim was shot. Table 3 shows articles about Gustillo II gunshot fractures

\section{Gustillo III gunshot fractures}

There is a consensus that meticulous debridement plays a key role in grade II and III Gustillo gunshot fractures, apparently more important than the initial the method of fixation in the primary management $[7,21]$. The fractures by Gustillo grade III firearms are related to higher energy injuries, more serious and with greater potential of complications, more common in victims of injuries of armaments of military use and explosives. The meticulous debridement plays a key role in fractures grade II and III Gustillo apparently more important in the initial assessment of the method of fixation. In war situations, the difficulties of access and transportation of wounded victims to centers of great trauma and the high destructive capacity of military weapons tend to suffer from more severe fractures. It can be said that there is a strong correlation between these high energy lesions and Gustillo's grade III fractures. There seems to be a tendency to perform damage control with external fixation in war zones and heavy urban armed conflicts (Figure 2).

Harwood's [22] concept of damage control was eventually applied to firearms fractures in the United States, which was already used in war environments, but without this designation. The main complications that are avoided are Respiratory Insufficiency, Fat Embolism and Venous Thromboembolism. The time for this conversion, so that there are no infectious complications, depends on the patient's evolution and their inflammatory and metabolic response to the trauma, but should not exceed 14 days. Nevertheless, Dar [23] conducted a prospective study with 41 patients with femoral gunshot fractures grade III of Gustillo. In the initial approach, external fixation was performed followed by intramedullary nailing. 



Figure 2: Gustillo type IIIC fracture of the proximal humerus by AK47 Rifle treated by damage control using external fixation and K wires (author's archive).

The mean conversion from placement of the external fixator to the closed intramedullary nail was about 26 days, with $100 \%$ of union. Olasinde [24] obtained good results in more severe gunshot fractures with delayed intramedullary fixation and bone grafting. The Table 4 below grouped studies that mention fractures by grade III firearms.

Dubravko [25] published, after attending FPA victims in the Croatian War, a study with a casuistry of 116 fractures, including 31 of femur, the lesions were treated by external fixation and the general incidence of osteomyelitis of $7.7 \%$ and $35 \%$ infection in the path of the pins. In war conflicts, the authors recommended external fixation.

Kaguru, et al. [26], in a study carried out in Congo, Africa treated 62 patients with limb war injuries with external fixation and venous antibiotic therapy and concluded that external fixators war limb injuries with fractures.

When performing a retrospective study in the conflicts in Jordan, Dahabra [27] recommends that 60 patients with
FAP fractures defended the use of external fixation for these lesions, regardless of fracture severity.

Lerner [28] widely use the external fixator in their reports to the victims of bomb attacks in Israel and, in an analysis of 47 patients with 64 fractures of the lower limbs in a war environment, treated the fractures with tube-to-tube external fixator at one moment, converting them to the Ilizarov type external fixator as definitive treatment after 5 to 7 days. At the end of the follow-up, more than $90 \%$ of the fractures were consolidated. Possley [29] had a $77 \%$ successful treatment of combat-related open tibia fractures with external fixation.

In Brazil, Amaral, et al. [30], in a comparative study with 26 patient's evaluated complex fractures of the forearm by high energy firearms treated with external fixator and immobilization. $57.1 \%$ of the patients treated with external fixator and $58.3 \%$ of those treated with plaster had satisfactory results. Among the patients treated with external fixation, $21.4 \%$ had infection, $14.3 \%$ had pseudoarthrosis and $7.2 \%$ 
had compartment syndrome. Among the patients treated with cast immobilization, $16.7 \%$ developed functional loss of supination and $8.3 \%$ with pseudoarthrosis. The group treated with external fixator had improvement in flexion-extension movements of the wrist. The study concludes that the ideal course is the initial use of orthosis until it is possible to perform rigid osteosynthesis.

The fixation methods are controversial in fractures by firearms Gustillo grade III and this is observed by the lack of standardization and studies with a high level of evidence to establish management and treatment protocols of this type of injury. The literature seems to a tendency to external fixation in war injuries and internal fixation in fractures in civilian hospitals. Nevertheless, controversies still remain. Nikolic [31] had poor results in subtrochanteric war gunshot fractures with external fixation. More recently, Fang [32], in a methanalysis comparing intramedullary nail and external fixation in Gustillo grade III tibial fractures was not conclusive about the best choice, but points that surgeons subjectively prefer external fixation followed by nailing, giving much attention to infection and sometimes forgetting that this procedure can also raise infection rates, because of reoperation, more time of hospitalization and higher malunion rates. As a matter of fact, more comparative studies with high level of evidence are necessary.

\section{Conclusion}

Immediate and early treatment with internal fixation can be recommended to Gustillo I gunshot fractures and uncomplicated Gustillo II gunshot fractures. As it can be observed, there is still controversy about the best technique to be used in exposed fractures type III of Gustillo. In the civilian environment, trauma centers tend to indicate immediate debridement and internal fixation as soon as soft tissue conditions are better. In war fractures by firearms, there seems to be a tendency for external fixation followed before internal definitive fixation and in some centers definitive external fixation. More studies with high level of evidence need to be published to stablish protocols.

\section{References}

1. Held M, Engelmann E, Dunn R, et al. (2017) Gunshot induced injuries in orthopedic trauma research. A bibliometrical analysis of the most influential literature. Revue de Chirurgie Orthopédique et Traumatologique 103.

2. Ribeiro AP, Souza ER, Sousa CAM (2017) Injuries caused by firearms treated at emergency and emergency services in Brazil. Ciênc Saúde coletiva 22: 9.

3. Manring MM, Hawk A, Calhoun JH, et al. (2009) Treatment of war wounds: A Historical Review. Clin Orthop Relat Res 467: 2168-2191.

4. Korzeniewski K, Bochniak A (2011) Medical support of military operations in Iraq and Afghanistan. Int Marit Health 62: 71-76.

5. Fackler ML (1988) Wound ballistics. A review of common misconceptions. JAMA 259: 2730-2736.

6. Durão C, Pinto R (2012) What the orthopedist needs to know about terminal ballistics. Rev Portuguese Ortop Traum 20: 167180.
7. Long WT, Chang W, Brien EW (2003) Grading System for Gunshot Injuries to the femoral diaphysis in civilians. Clin Orthop Rel Res 408: 92-100.

8. Gustillo RB, Anderson JT (1976) Prevention of infection in the treatment of 1021 open fractures of the long bones: retrospective and prospective analysis. J Bone Joint Surg 58: 453-458.

9. Gustilo RB, Mendoza RM, Williams DN (1984) Problems in the management of type III (severe) open fractures. A new classification of type III open fractures. J Trauma 24: 742-746.

10. Noumi T, Yokoyama K, Ohtsuka H, et al. (2005) Intramedullary nailing for open fractures of the femoral shaft: evaluation of contributing factors on deep infection and nonunion using multivariate analysis. Injury 36: 1085-1093.

11. Papasoulis E, Patzakis MJ, Zalavras CG (2013) Antibiotics in the treatment of low-velocity gunshot-induced fractures: A systematic literature review. Clin Orthop Realt Res 471: 3937-3944.

12. Wiss DA, Brien WW, Becker V Jr (1991) Interlocking nailing for the treatment of femoral fractures due to gunshot wounds. J Bone Joint Surg Am 73: 598-606.

13. Bergman $M$, Tornetta $P$, Kerina $M$, et al. (1993) Femur fractures caused by gunshots: Treatment by immediate reamed intramedullary nailing. J Trauma 34: 783-785.

14. Nowotarski P, Brumback RJ (1994) Immediate interlocking nailing of fractures of the femur caused by low mid-velocity gunshots. J Orthop Trauma 8: 134-141.

15. Polat G, Balci HI, Ergin ON, et al. (2018) A comparison of external fixation and locjed intramedullary nailing in the treatment of femoral diaphysis fractures from gunshot injuries. Eur J Trauma Emerg Surg 44: 451-455.

16. Tornetta P, Tiburzi D (1994) Anterograde interlocked of distal femoral fractures after gunshot wounds. J Orthop Trauma 8: 220-227.

17. Molinari RW, Yang EC, Strauss E, et al. (1994) Timing of internal fixation in low-velocity extremity gunshot fractures. Contemp Orthop 29: 335-339.

18. Gonzalez MH, McKay W, Hall RF Jr (1993) Low-velocity gunshot wounds of the metacarpal: Treatment by early stable fixation and bone grafting. The Journal of Hand Surgery 18.

19. Kiehn MW, Mitra A, Gutowski KA (2005) Fracture management of civilian gunshot wounds to the hand. Plast Reconstr Surg 115: 478-481.

20. Kömürcü $M$, Alemdaroğlu $B$, Kürklü $M$, et al. (2008) Handgun injuries with metacarpal and proximal phalangeal fractures: Early definitive treatment. INT orthop 32: 257-262.

21. Fries CA, Ayalew Y, Penn-Barwell JG, et al. (2014) Prospective randimized contorlled trial of naocrystalline silver dressing versus plain gauze as the initial post-debridement management of military wounds on wound microbiology and healing. Injury 45: 1111-1116.

22. Harwood PJ, Giannoudis PV, van Griensven M, et al. (2005) Alterations in the systemic inflammatory response after early total care and damage control procedures for femoral shaft fracture in severely injured patients. J Trauma 58: 446-452.

23. Dar GN, Tak SR, Kangoo KA, et al. (2009) External fixation followed by delayed interlocking intramedullary nailing in high velocity gunshot wounds of the femur. Ulus Travma Acil Cerrahi derg 15: 553-558. 
24. AA Olasinde, JD Ogunlusi, IC Ikem (2012) Outcomes of the treatment of gunshot fractures of lower extremities with interlocking nails. SA Orthop Journal 11.

25. Dubravko H, Zarko R, Tomislav T, et al. (1994) External fixation in war trauma management of extremities- experience from the war in Croatia. J Trauma 37: 831-834.

26. N Kagukul, V Reinekainnen, Luhiriri, et al. (2004) The use of external fixator in the management of gunshot open limb fractures. East and Central African Journal of Surgery 9: 41-43.

27. Dahabra IA, Sawaqed IS, Soudi MN (1994) Treatment of gunshot open fractures by external fixator: Experience at King Hussein Medical Center. J Trauma 37: 831-834.
28. Lerner A, Fodor L, Soudry M (2006) Is staged external fixation a valuable strategy for war injuries to the limbs? Clin Orthop Relat Res 448: 217-224.

29. Possley DR, Burns TC, Stinner DJ, et al. (2010) Temporary external fixation in a safe combat envinroment. J Trauma 69: S135-S139.

30. Amaral NP, Giordano V, Gonçalves AP, et al. (2007) Complex fracture of forearm bones caused by high energy firearm shells: External fixation versus cast apparatus. Rev Bras Ortop 42: 47-54.

31. Nikolić D, Jovanović Z, Turković G, et al. (1998) Subtrochanteric missile fractures of the femur. Injury 29: 743-749.

32. Fang $X$, Jiang L, Wang $Y$, et al. (2012) Treatment of Gustillo grade III tibial fractures with unreamed intramedullary nailing versus external fixator: The meta analysis. Med Sci Monit 18: 49-56. 